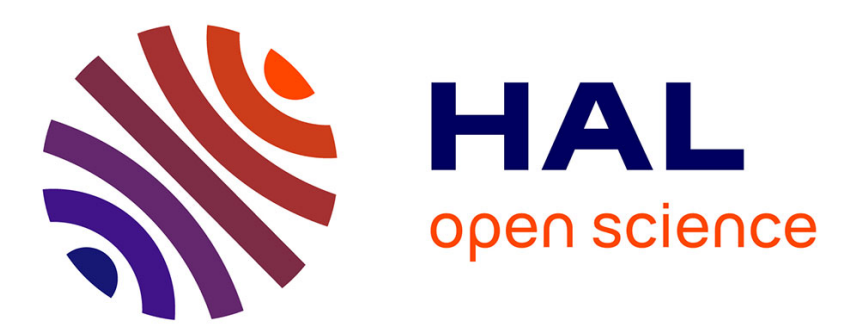

\title{
Changes in Cell Wall Structure During Rhizoid Formation of Silvetia babingtonii (Fucales, Phaeophyceae) Zygotes
}

Rina Yonamine, Kensuke Ichihara, Shiro Tsuyuzaki, Cécile Hervé, Taizo Motomura, Chikako Nagasato

\section{To cite this version:}

Rina Yonamine, Kensuke Ichihara, Shiro Tsuyuzaki, Cécile Hervé, Taizo Motomura, et al.. Changes in Cell Wall Structure During Rhizoid Formation of Silvetia babingtonii (Fucales, Phaeophyceae) Zygotes. Journal of Phycology, 2021, 57 (4), pp.1356-1367. 10.1111/jpy.13178 . hal-03374429

\author{
HAL Id: hal-03374429 \\ https://hal.science/hal-03374429
}

Submitted on 26 Oct 2021

HAL is a multi-disciplinary open access archive for the deposit and dissemination of scientific research documents, whether they are published or not. The documents may come from teaching and research institutions in France or abroad, or from public or private research centers.
L'archive ouverte pluridisciplinaire HAL, est destinée au dépôt et à la diffusion de documents scientifiques de niveau recherche, publiés ou non, émanant des établissements d'enseignement et de recherche français ou étrangers, des laboratoires publics ou privés. 
1 CHANGES IN CELL WALL STRUCTURE DURING RHIZOID FORMATION OF

2 SILVETIA BABINGTONII (FUCALES, PHAEOPHYCEAE) ZYGOTES ${ }^{1}$.

3

4 Rina Yonamine

5 Graduate School of Environmental Science, Hokkaido University, Sapporo 060-0810,

6 Japan

7

8 Kensuke Ichihara

9 Muroran Marine Station, Field Science Center for Northern Biosphere, Hokkaido

10 University, Muroran 051-0013, Japan

11

12 Shiro Tsuyuzaki

13 Graduate School of Environmental Earth Science, Hokkaido University, Sapporo 060-

14 0810, Japan

15

16 Cécile Hervé

17 Sorbonne Universités, CNRS, Integrative Biology of Marine Models (LBI2M), Station

18 Biologique de Roscoff, 29680 Roscoff, France

19

20 Taizo Motomura

21 Muroran Marine Station, Field Science Center for Northern Biosphere, Hokkaido

22 University, Muroran 051-0013, Japan

23

24 Chikako Nagasato ${ }^{2}$ 
1 Muroran Marine Station, Field Science Center for Northern Biosphere, Hokkaido

2 University, Muroran 051-0013, Japan

3

$4 \quad{ }^{2}$ Author for correspondence: e-mail nagasato@ fsc.hokudai.ac.jp, phone: +81-143-22-

5 2846, fax: +81-143-22-4135

6

7

8 Running Title: Cell wall in the rhizoid formation of Silvetia zygotes

9 


\section{ABSTRACT}

2

3 alginates using specific antibodies against M-rich alginates and MG blocks during

4 rhizoid formation in fucoid zygotes, Silvetia babingtonii. The thallus region on the 24-

5 hour old zygotes was composed of a cell wall made of three layers with different fiber

6 distribution. In the 10-hour old zygotes, three layers in the thallus were observed before

7 rhizoid formation, namely the inner, middle and outer layers. During rhizoid elongation,

8 only the inner layer was apparent close to the rhizoid tip area. Immunoelectron

9 microscopy detected M-rich blocks of alginate on the inner half of the cell wall,

10 irrespective of the layer number in the thallus and rhizoid regions. The MG blocks were

11 seen to cover a slightly wider area than M-rich alginate blocks. This likely indicates an

12 alginate deposition on its mannuronate form close to the plasma membrane before

13 subsequent maturation, and MG-blocks generation, in the wall. Transcriptome analysis

14 was performed using 3 -, 10 -, and 24 h-old zygotes after fertilization to examine gene

15 expression level relating alginate synthesis on this time course. The expression level of

16 two mannuronan C5-epimerase homologs in particular, which have the function of

17 conversion of mannuronic acid into guluronic acid in alginates, was upregulated or

18 downregulated over the course of the examination.

19

20 Keywords: cell wall, cryofixation, immunoelectron microscopy, RNA-seq, Silvetia

babingtonii, transmission electron microscopy 
1 Abbreviations: AF, after fertilization; BAM, brown algae monoclonal antibody; MC5E,

2 mannuronan C5-epimerase; RFCW, Rhizoid-flank cell wall; G, Guluronic acid; M,

3 Mannuronic acid; RTCW, Rhizoid-tip cell wall; TCW, Thallus cell wall

4

\section{INTRODUCTION}

Many seaweeds grow in the intertidal region where environmental factors,

7 including temperature, wave shock, intensity and quality of light, salinity, and drying,

8 are changeable. The cell wall protects the cell structure from physical shocks and

9 unfavorable factors, such as herbivores. Therefore, seaweeds develop characteristic

10 polysaccharides in the cell wall to enhance stress tolerance (Kloareg and Quatrano

11 1988, Popper et al. 2011). In brown algae, the main components of the cell wall are

12 alginates, sulfated fucans, and cellulose. In the mature sporophyte of laminarialean and

13 fucalean species, the weight ratio of alginate is three times and more than half that of

14 cellulose and sulfated fucan (Mabeau and Kloareg 1987, Skriptsova et al. 2012).

15 Alginate consists of 1,4 linked mannuronic acid (M) and guluronic acid (G) residues.

16 M-rich blocks show flexible gels, while G-rich blocks cause rigidity. Accordingly, the

$17 \mathrm{M} / \mathrm{G}$ ratio relates to the properties of the cell wall, such as gel strength and stretching.

18 Young sporophytes of Costaria costata show a high M/G ratio, and the ratio gradually

19 decreases with thallus growth (Wu et al. 2014). The conversion of $\mathrm{M}$ residue into $\mathrm{G}$

20 residue is carried out by different mannuronan C5-epimerases (MC5E) expressed in

21 different developmental stages and environmental conditions (Nyvall et al. 2003, Tonon

22 et al. 2008). The alginate biosynthesis pathway in brown algae is not fully resolved,

23 especially the first production of a polymer of M residues (mannuronan) (Michel et al.

24 2010). It is predicted that, shortly after synthesis, the alginate should consist of M-rich 
1 blocks; therefore, the M-rich region might hold the clues to the understanding of

2 alginate synthesis.

3

4 The results showed that three or more cell wall layers were identified in the apical cell

5 of Sphacelaria rigidula (Karyophyllis et al. 2000), the meristematic epidermal cells of

6 Dictyota dichotoma (Evans and Horrigan 1972), zygotes of fucoid algae (Novotny and

7 Forman 1975, Callow et al. 1978, Bisgrove and Kropf 2001), and the lateral cell wall in

8 gametophytes and sporophytes of Ectocarpus siliculosus (Terauchi et al. 2016). The cell

9 wall layers were distinguished by the distribution of the cell wall fibers and the matrix.

10 Terauchi et al. (2016) clarified the quantification of the frequency of the electron-dense

11 fibrils (alginate fibrils) and their junction based on three-dimensional analysis using rapid freezing fixation and electron microscopy and tomography. The results showed that the alginate fibers were distributed more densely and in a more complex arrangement in the inner layer than in the middle layer.

Tip-growing apical cells of Sphacelaria showed a characteristic cell wall structure. In Sphacelaria rigidula, the apical dome of the tip cell had a two-layered cell wall. A very thin amorphous layer (L1) covered the cell, and the fibrous layer (L2) existed just beneath the L1 layer. Other parts of the tip cell and the thallus cells were covered with four layers of cell walls, with L3 and L4 added to L1 and L2 (Karyophyllis et al. 2000). In Sphacelaria furcigera, bud (branch) formation was observed (Burns et al. 1982a, b). The axial cell wall is composed of four layers (CW1CW4), but the initial bud region is covered by two newly synthesized layers (CWO and CWI). Burns et al. (1982a) suggested that alginates are abundant in CW2, CW4, and CWI, while sulfated fucans were prominent in CW1, CW3, and CWO. Cell wall 
1 structure on the rhizoid tip in fucoid zygotes has been observed (Novotny and Forman

2 1975, Callow et al. 1978, Bisgrove and Kropf 2001). Deposition of the highly sulfated

3 fucan occurs in the tip growth region (Quatrano and Crayton 1973, Quatrano and Steven

4 1976, Callow et al. 1978, Brawley and Quatrano 1979, Torode et al. 2016). However,

5 the changes occurring in the cell wall structure during rhizoid development remain

6 unclear.

7

8 cell wall components, which would produce different physicochemical properties. To

9 examine the distribution of polysaccharides on the cell wall, immunoelectron

Different appearances in the multilayered cell wall could reflect differences in microscopy using anti-alginate antibody (Chi et al. 1999, Nagasato et al. 2010, Terauchi et al. 2012, Terauchi et al. 2016), an anti-fucoidan antibody (Nagasato et al. 2010), and a binding assay using a conjugation of cellulase or alginate lyase-colloidal gold were applied (Nagasato et al. 2010, Terauchi et al. 2016). At the light microscopic level, metachromatic analysis using toluidine blue and periodic acid-Schiff (PAS) was performed to detect alginate and sulfated fucan (Novotny and Forman 1975, Burns et al. 1982a). Recently, monoclonal antibodies that recognize the different structures of alginate and sulfated fucan have been produced, and immunofluorescence data on the localization of these epitopes in some brown algal species have been collected (Torode et al. 2016, Linardić et al. 2017, Rabillé et al. 2019, Linardić et al. 2020). Antibodies recognizing different epitopes showed spatial and temporal differences in localization. By analyzing the localization of these antibodies through immunoelectron microscopy, it was expected that we could obtain more useful information relating to the multilayered cell wall of the brown algae. 
In brown algae, there is little existing information on how the cell wall changes

2 to generate tip-growth from the thallus cell. To address this question, we observed cell

3 wall structure during rhizoid growth in the fucoid alga Silvetia babingtonii zygotes,

4 using the rapid freezing and freeze substitution technique for transmission electron

5 microscopy (TEM). This method is an effective method for preventing from eliminating

6 the soluble polysaccharides, namely alginate and fucan. In this study, we focused on

7 localization of the alginate by immunoelectron microscopy using antibodies recognizing

8 different epitopes. Moreover, to examine the synthesis regulation of alginate on rhizoid

9 growth, transcriptome analysis using mRNA obtained from zygotes before and after

10 rhizoid germination was conducted.

MATERIALS AND METHODS

Materials

15 Brawley was collected from September to November 2006-2010 at Charatsunai, and

162018 at Botofurinai, Muroran, Hokkaido, Japan. The zygote preparation procedure was

17 the same as in the previous paper (Nagasato et al. 2010). The collected mature thalli

18 were brought to the laboratory and wiped with gauze after washing with sterile

19 seawater. They were placed in continuous light $\left(30-40 \mu \mathrm{mol}\right.$ photons $\left.\cdot \mathrm{m}^{-2} \cdot \mathrm{s}^{-1}\right)$ at $18^{\circ} \mathrm{C}$

20 overnight. Then, the thalli were transferred to a cool chamber at $4{ }^{\circ} \mathrm{C}$ for $2 \mathrm{~h}$ after

21 darkening with aluminum foil. Adding fresh seawater induced the release of eggs and

22 sperm into the medium. The age of the zygotes was counted from one $\mathrm{h}$ after pouring

23 seawater. Zygotes were cultured in PES medium (Provasoli 1968) containing $40 \mu \mathrm{g} \cdot \mathrm{mL}^{-}$

$24{ }^{1}$ chloramphenicol at $18{ }^{\circ} \mathrm{C}$ in continuous light. 
2 Electron microscopy and Immunoelectron microscopy

4 fixation, the films were cut into small triangle shapes less than $1 \mathrm{~cm}$. Rapid freezing and

5 freeze substitution procedures were performed according to previous reports (Nagasato 6 and Motomura 2002, Nagasato et al. 2010). Finally, the samples were embedded in a

7 Spurr low-viscosity resin (Polyscienes, Warrington, USA). Ultrathin sections were cut

8 using a diamond knife on an ULTRACUT ultramicrotome (Reichert-Jung, Vienna,

9 Austria). Sections were picked up on a formvar-coated one-slot copper grid, stained

10 with EM stainer (Nisshin EM, Tokyo, Japan) and then lead citrate (Reynolds 1963).

11 Observations were performed using a JEM-1011 electron microscope (JEOL, Tokyo, 12 Japan).

13 Localization of the alginate was examined using antibodies against various 14 alginate blocks (Torode et al. 2016). Nickel grids with sections were incubated with 15 blocking solution (2.5\% skimmed milk, $5 \%$ normal goat serum, and $0.05 \% \mathrm{NaN}_{3}$ in $16 \mathrm{PBS} ; 137 \mathrm{mM} \mathrm{NaCl}, 2.7 \mathrm{mM} \mathrm{KCl}, 4.9 \mathrm{mM} \mathrm{Na}_{2} \mathrm{HPO}_{4}, 1.5 \mathrm{mM} \mathrm{KH}_{2} \mathrm{PO}_{4}, \mathrm{pH} 7.4$ ) for 30 $17 \min$ at $37{ }^{\circ} \mathrm{C}$ and then transferred to anti-alginate antibodies, BAM6 and BAM7 diluted 18 1:5 with PBS for $1 \mathrm{~h}$ at $37^{\circ} \mathrm{C}$. The grids were then washed with PBS three times and 19 incubated for $1 \mathrm{~h}$ at $37{ }^{\circ} \mathrm{C}$ with a goat anti-rat $\operatorname{IgG}$ (whole molecule) conjugated with 10 nm colloidal gold particles (Sigma) diluted 1:20 with blocking solution. After washing

21 with PBS and distilled water, sections on the grids were performed using an EM stainer 22 in this case.

24 Quantification of colloidal gold particles 
2 rhizoid-tip cell wall (RTCW), the distance between each colloidal gold particle and

3 plasma membrane was measured using ImageJ 64 (NIH, Bethesda, MD, USA).

4 Measurements were conducted for three rectangles with the height of the cell wall from

5 the plasma membrane and $0.75 \mu \mathrm{m}$ width on the same cell wall region against three

6 zygotes $(n=9)$. The thickness of the cell wall differed in each sample; thus, the length

7 between the plasma membrane and the edge of the cell wall was set as one. The

8 conditions that labeled the density of gold particles within $0.25 \mu \mathrm{m}^{2}$ exceeded 10 (Table

9 1) were performed in this analysis. The distance of gold particles was assumed to follow

10 a beta distribution because the distance was continuous and ranged from 0 to 1 . Because

11 the number of particles differed between the antibodies, the relative density of distance

12 was used to investigate the distributions. The kernel function and bandwidth obtained

13 the function to express the density. Assessment of the function was confirmed by

14 goodness of fit tests (GFT). Beta regression was used to investigate the effects of

15 antibodies (BAM6 and BAM7), and the cell wall regions (TCW and RTCW) used as

16 explanatory variables, on the distance, used as a response variable. Since interactions

17 between these three explanatory variables were unlikely, the analyses were conducted

18 on the respective explanatory variables. All statistical analyses were performed using R

19 software (version 4.0.2) (R Core Team 2020) with the libraries fitdistrplus (Delignette-

20 Muller and Dutang 2015) and betareg (Cribari-Neto and Zeileis 2010).

RNA-seq and differential expression analysis

24 using cetyltrimethylammonium bromide (CTAB) buffer (Pearson et al. 2006). The 
extract was purified with a chloroform-isoamyl alcohol solution $(24: 1 \mathrm{v} / \mathrm{v})$. After

2 precipitation with $3 \mathrm{M} \mathrm{LiCl}$, contaminating DNA was removed with an RNase-free

3 DNase Set (Qiagen, Hilden, Germany). Total RNA samples with OD260/280 >1.8,

4 OD260/230>2.0, were used for library construction.

The cDNA library construction, sequencing with Illumina Novaseq6000 (150

6 bp paired-ends), and generating clean reads by filtering raw reads were performed by

7 Filgen Inc. (Nagoya, Japan). The clean reads were assembled using Trinity software

8 (Haas et al. 2013). The assembled contigs were clustered and filtered out using CD-

9 HIT-EST on CD-HIT suite server (Li and Godzik 2006) with 90\% similarity, and the

10 longest open reading frame (ORF) sequences were identified by TransDecoder (v5.5.0)

11 (Haas et al. 2013). Sequences with less than 100 amino acids were discarded. The

12 longest ORF sequences were annotated using the annotation pipeline on Maser

13 (Management and Analysis System for Enormous Reads) platform (https://cell-

14 innovation.nig.ac.jp) (Kinjo et al. 2018). Clean reads were aligned onto the longest ORF

15 sequences and quantified using Salmon (Patro et al. 2017). Data normalization and

16 identification of differentially expressed genes (DEGs) without replicates were

17 performed using an iterative deseq pipeline in the TCC package (Sun et al. 2013). False

18 discovery rates $($ FDR $) \leq 0.05$ were considered as DEGs. The Z-scores based on the

19 transcripts per million (TPM) were calculated using R software (3.6.2; http://www.R-

20 project.org/), and the heatmap of genes for the biosynthetic pathway of alginates was

21 drawn using the gplots (3.0.1.2) package. The Bioconductor package topGO version

22 2.38.1 (Alexa et al. 2006) were used for Gene Ontology (GO) enrichment analysis in R

23 software. Over-representative Go terms in up-regulated or down-regulated genes in

24 three comparison conditions ( $3 \mathrm{~h}$ AF vs $10 \mathrm{~h} \mathrm{AF}, 3 \mathrm{~h}$ AF vs $24 \mathrm{~h} \mathrm{AF}$ and $10 \mathrm{~h}$ AF vs 24 
$1 \mathrm{~h} \mathrm{AF}$ ) were identified by Fisher's exact test in combination with the 'weight' algorithm,

2 using a minimum p-value cut-off of 0.01 .

3

$4 \quad$ Real-Time qPCR analysis

To analyze the transcriptional expression of DEG, RT-qPCR was performed.

6 Synthesize of cDNA as template was performed by PrimeScript ${ }^{\mathrm{TM}}$ RT reagent Kit with

7 gDNA Eraser (TaKaRa, Shiga, Japan) using total RNA 50 ng in $20 \mu 1$ reaction mixture

8 according to manufacture protocol. Specific primers for each contig were designed

9 using Primer-BLAST (Table S1). The reaction mixture contained $5 \mu$ L SYBR Premix

10 Ex Taq II (TaKaRa), $0.4 \mu \mathrm{l}$ specific primers $(10 \mu \mathrm{M})$, and $1 \mu \mathrm{l}$ cDNA template in a total

11 of $10 \mu$ l. qPCR was performed using Eco Real-Time PCR system (Illumina, San Diego,

$12 \mathrm{CA}$, USA). After $95^{\circ} \mathrm{C}$ for $30 \mathrm{~s}$, the cycling parameters were $95^{\circ} \mathrm{C}$ for $5 \mathrm{~s}$, and $60{ }^{\circ} \mathrm{C}$

13 for $1 \mathrm{~min}$ and were performed for 40 cycles. The melting curve analysis was as follows:

$1495^{\circ} \mathrm{C}$ for $15 \mathrm{~s}, 55^{\circ} \mathrm{C}$ for $15 \mathrm{~s}$, and $95^{\circ} \mathrm{C}$ for $15 \mathrm{~s}$. Transcript levels corresponding to the

15 comp32408_c2_seq24.p1and comp33109_c0_seq1.p1 genes (putative mannuronan C5-

16 epimerase) were compared with the transcript levels of the actin gene (actin;

17 comp21090_c0_seq1.p1). The RT-qPCR was performed in triplicate using three RNA

18 samples from each zygote at the ages of 3,10 , and $24 \mathrm{~h}$. The differences in mean

19 relative expression level between the developmental hours (3, 10, and $24 \mathrm{~h})$ were

20 examined by Tukey's multiple comparison test.

21

22 Identifying mannuronan C5-epimerase from S. babingtonii assembled contigs and

23 molecular phylogenetic analysis 
2 Ectocarpus siliculosus (http://bioinformatics.psb.ugent.be/orcae/overview/EctsiV2) was

3 also conducted to identify genes for enzymes in the biosynthetic pathway of alginates

$4 \quad$ using BLAST+ version 2.7.1

5 (ftp://ftp.ncbi.nlm.nih.gov/blast/executables/blast+/LATEST). To construct the MC5E

6 phylogenetic tree, 36 sequences from E. siliculosus

7 (https://bioinformatics.psb.ugent.be/orcae/overview/EctsiV2), one sequence from

8 Saccharina japonica (Inoue et al. 2016), and seven sequences from assembled $S$.

9 babingtonii contigs were gathered. Three bacterial AlgG sequences from Azotobacter

10 vinelandii (P70805), Pseudomonas aeruginosa (Q51371), and P. fluorescens (P59828)

11 were added to the alignment file as an outgroup. Phylogenetic analysis of amino acid

12 sequences of MC5E was carried out using web service NGphylogeny.fr

13 (https://ngphylogeny.fr/) (Lemoine et al. 2019). The sequences were aligned using

14 MAFFT with the iterative refinement method and the scoring matrix Blosum62 (Katoh

15 et al. 2002). Ambiguously aligned non-informative regions were removed with BMGE

16 (Criscuolo and Gribaldo 2010). Twenty sequences were removed due to insufficient

17 sequence length or having identical sequences to the others from the phylogenetic

18 analysis. The model test for maximum likelihood (ML) method was carried out by SMS

19 (Lefort et al. 2017), and phylogenetic analysis was performed using PhyML (Guindon

20 et al. 2010). The best-fit model was Blosum $62+\mathrm{G}+\mathrm{I}+\mathrm{F}$ based on Akaike information

21 criteria (AIC). Bootstrap values (Felsenstein 1985) were obtained from the analyses of

22100 pseudoreplicates with Booster (Ehman et al. 2018). The domain searches against

23 the InterPro server (https://www.ebi.ac.uk/interpro/) were also carried out. 


\section{RESULTS}

2

3

4

Immediately after fertilization, the Silvetia zygotes showed a spherical shape (Fig. 1a) and rhizoid generation initiated at $12 \mathrm{~h}$ after fertilization (AF) (Fig. 1b). The first and second cytokinesis occurred at $20 \mathrm{~h}$ and $24 \mathrm{~h} \mathrm{AF}$, respectively (Fig. 1c, d). We observed the ultrastructure and the alginate occurrence of the cell walls in the zygotes after $12 \mathrm{~h}$ and $24 \mathrm{~h}$ AF. Three cell areas were observed in terms of cell wall structures (Fig. 1e): (i) the thallus cell wall (TCW), (ii) the rhizoid-flank cell wall (RFCW), and (iii) the rhizoid-tip cell wall (RTCW).

At $12 \mathrm{~h} \mathrm{AF}$, the TCW was filled with an electron-dense structure with paralleloriented fibrils (Fig. 2a). In the RFCW, three layers with different contrasts, dark-lightdark, were visible (Fig. 2b). The RTCW showed less stainability and irregularly oriented fibrils (Fig. 2c). The cell wall structure in the zygotes at $24 \mathrm{~h}$ AF was examined (Fig. 3a). The appearance of the TCW was dependent on the cutting angle of the ultra-thin sections to the cell wall and the plasma membrane. The section by an oblique angle of the cell wall to the plasma membrane revealed three distinct layers with different stainability and fiber-running orientation (Fig. 3b). The cell wall was roughly divided in three equal parts with the inner (IL), middle (ML) and outer (OL) layers representing 31,35 and $34 \%$ of the whole cell wall, respectively. However, it was difficult to define each layer on a perpendicular section of the cell wall to the plasma membrane because of high electron density (Fig. 3c), as in 12 hour-old zygotes (Fig. S1a). In the RFCW, the outer and middle layers were hardly observed (Fig. 3d, e). First, the outer layer is not apparent at the base of the rhizoid tip (the site indicated by a double arrowhead in Fig. 3a), and the middle layer faded away subsequently. The remaining inner layer became thicker closer to the rhizoid tip (Fig. 3f). While well- 
structured in other regions, the distribution of fibrils was irregular or wavy closer to the

2 tip. The mucilage material covered the outside of the rhizoid. The amorphous

3 mucilaginous layer was not included in the numbering of the cell wall layer in this

4 study.

To locate alginate epitopes in the different cell wall regions, immunoelectron

6 microscopy using anti-alginate antibodies was conducted in zygotes at the age of $24 \mathrm{~h}$

7 (Fig. 4). Localization of M-rich blocks detected by BAM6 antibody was found in the

8 inner half of the TCW, RFCW, and RTCW (Fig. 4a, b, c). The labeling density of gold

9 particles using BAM6 on the RFCW within $0.25 \mu \mathrm{m}^{2}$ was small (Fig. 4b, Table 1),

10 compared with that in the other two regions. MG-alginates, as detected by the BAM7

11 antibody, were more thoroughly distributed along the wall than MM-blocks, and with

12 dense occurrences (Fig. 4d, e, f). The mean value of the density of gold particles using

13 BAM7 was clearly higher in the order of RTCW, RFCW, and TCW (Table 1).

14 The width of cell wall between the plasma membrane and the edge of the cell

15 wall was set as one and divided into ten section. Distribution patterns on the relative

16 distance, ranging from 0 to 1 , of gold particles in the cell wall were estimated well by

17 the function fitted at 10 segments (GFT, P $<0.01$ for all cases) (Fig. S1). The density of

18 particles binding to BAM6 in the control peaked at a distance of approximately 0.3 ,

19 which was consistent with the boundary between the inner and middle layers. The

20 density distributions of distances were flatter for BAM7, with a range of 0 to 0.8 , than

21 for BAM6 in TCW with shifts of peaks from short at 0.3 to long distances at 0.6 (beta

22 regression, $\mathrm{z}=-6.193, \mathrm{P}<0.001)$. These results showed that the gold particles binding

23 to BAM7 were distributed close to plasma membrane compared with BAM6. The

24 relative densities of distance in TCW showed another peak at 0.7 of relative distance. 
To understand the genes involved in early embryo development, transcriptomic

2 analysis was performed at three different developmental stages ( $3 \mathrm{~h} \mathrm{AF}$ : time of

3 increased wall thickness, $10 \mathrm{~h} \mathrm{AF}$ : time of initiation of rhizoid germination, and $24 \mathrm{~h}$

4 AF: time that the second cytokinesis finished and the rhizoid elongated) (Fig. S2). The

5 obtained short reads data are summarized in Table S2. De novo assembly produced

697,825 contigs. Filtering with CD-HIT-EST reduced the size of the assembly to 78,268

7 contigs, and the 27,622 longest ORF contigs were detected by TransDecoder. A total of

811,087 contigs (40\%) were annotated by BLASTX for UniProt database (Table S3), and

$9 \quad 61-63 \%$ of reads were mapped to the 25,890 longest ORF contigs. Then, differential

10 expressed genes (DEGs) were detected for 107 contigs in $3 \mathrm{~h} \mathrm{AF} \mathrm{vs.} 10 \mathrm{~h} \mathrm{AF,} 47$

11 contigs in $3 \mathrm{~h}$ AF vs. $24 \mathrm{~h} \mathrm{AF}, 125$ contigs in $10 \mathrm{~h}$ AF vs. $24 \mathrm{~h}$ AF of the 25,890 contigs

12 (Fig. S3; Tables S4-S6). GO enrichment analysis indicates that sulfotransferase activity

13 (GO:0008146) and extracellular region (GO:0005576) were significant in the down-

14 regulated genes on $24 \mathrm{~h} \mathrm{AF}$ (Table S7).

15 Reciprocal best-hit blast against Ectocarpus siliculosus reference proteins

16 showed 39.6\% $(9,699)$ proteins in S. babingtonii longest ORF contigs (Table S7 $\underline{\text { S8)}}$ ).

17 The BLAST search indicated that some alginate synthetic pathway enzymes, two

18 mannose-6-phosphate isomerase (MPI), one phosphomannomutase (PMM), one GDP-

19 mannose 6-dehydrogenase (GMD), and seven MC5E, were conserved in S. babingtonii.

20 The expression patterns of these enzyme genes are summarized in Fig. S4). The

21 expression levels of $M P I$ (comp32248_c1_seq4.p1) and GMD

22 (comp32002_c0_seq6.p1) remained stationary throughout the experiment. Five MC5Es

23 (comp12459_c0_seq1.p1, comp21318_c0_seq3.p1, comp25876_c0_seq1.p1,

24 comp32408_c2_seq24.p1 and comp32951_c0_seq4.p1) were up-regulated as the 
1 developmental stage proceeded, and one (comp33109_c0_seq1.p1) was slightly

2 suppressed in $24 \mathrm{~h} \mathrm{AF}$.

3 Domain search and phylogenetic analysis of MC5Es to clarify the molecular

4 function were performed. The catalytic MC5E domain. And the signal peptide region

5 was detected in four contigs (Fig. S5). The phylogenetic tree of MC5Es shows five

6 clades supported with high to moderate value (42-100\%) and seven MC5Es homologs

7 of S. babingtonii were scattered within these five clades (Fig. S5). Two MC5E

8 homologs (comp32408_c2_seq24.p1 and comp33109_c0_seq1.p1) were detected as

9 DEGs in different embryo development stages. RT-qPCR was carried out on two

10 contigs (comp32408_c2_seq24.p1 and comp33109_c0_seq1.p1) (Fig. 5). The

11 expression level of comp32408_c2_seq24.p1stayed lower until $10 \mathrm{~h}$ AF and increased

12 eight times at $24 \mathrm{~h}$ AF. Comp33109_c0_seq1.p1 expression level declined to one-fifth 13 at $10 \mathrm{~h} \mathrm{AF}$ from $3 \mathrm{~h} \mathrm{AF}$.

\section{DISCUSSION}

17 fucoid zygotes have been reported (Novotny and Forman 1975, Vreugdenhil et al. 1976,

18 Callow et al. 1978, Bisgrove and Kropf 2001). Previous studies have shown that the cell

19 wall of the thallus region consists of two layers, and the rhizoid cell wall structure has a one or two layers (Novotny and Forman 1975, Vreugdenhil et al. 1976, Callow et al.

21 1978, Bisgrove and Kropf 2001). We observed three layers in TCW in Silvetia

22 babingtonii zygotes at $24 \mathrm{~h} \mathrm{AF}$. Occasionally, it was difficult to define the number of

23 layers in the TCW, even in the same zygote. The cutting angle of the section affects the

24 appearance of the cell wall structure (Terauchi et al. 2016). To avoid this, we prepared 
1 consecutive serial sections in each zygote and observed the cell wall structure. Bisgrove

2 and Kropf (2001) mentioned a porous area adjacent to the plasma membrane within the

3 thicker inner layer using chemical fixation. Although they did not count it as another

4 layer, we considered that the porous area corresponds to the inner layer observed in the

5 present study using rapid-freezing and freeze substitution (Fig. 3b).

$6 \quad$ Regarding the rhizoid cell wall, we observed that the two outer and middle

7 layers from the thallus region were not apparent at the RFCW, and only the inner layer

8 surrounded the rhizoid tip. The inner layer became gradually thicker, and the cell wall

9 fibrils showed an irregular orientation close to the rhizoid tip. This observation is the

10 first to explain how cell wall structure changes during rhizoid elongation in fucoid

11 zygotes at the ultrastructural level. We considered that the cleavage of the two outer

12 layers occurred during rhizoid elongation, not during its initiation. In the RTCW of the

13 zygote at $12 \mathrm{~h} \mathrm{AF}$, namely, the stage of initiation of rhizoid elongation, the cell wall

14 layer could not be clearly seen (Fig. 2c); however, the three layers were observed in the

15 RFCW (Fig. 2b). At the beginning of tip growth, the three layers extended; however,

16 the outer two layers might break by limitation of extension according to the further

17 outgrowth. On the other hand, the inner layer could be extended by the addition of new

18 cell wall materials and remodeling.

19 In land plants, an ultrastructure in the tip growth region is observed during root

20 hair and pollen tube growth. In Arabidopsis thaliana, the growing root hair cell wall

21 shows a single layer, and the mature one is surrounded by two layers with different

22 textures and orientation of microfilaments (MFs) (Akkerman et al. 2012). A similar

23 pattern has been observed in Equisetum hyemale (Emons and Wolters-Arts 1983).

24 Expansin, a protein that promotes cell wall loosening without degradation of cell wall 
1 polymers, is involved in root hair initiation and elongation in many land plants (Cho

2 and Cosgrove 2002, Cosgrove 2015). The apical dome of the pollen tube consists of an

3 outer layer with pectin and a translucent inner layer with callose and cellulose in $A$.

4 thaliana (Dardelle et al. 2010, Chebli et al. 2012) and Nicotiana tabacum (Geitmann et

5 al. 1995, Ferguson et al. 1998). In the apical dome of the outer layer, highly esterified

6 pectin deposits are created by exocytosis, while localization of low-esterified pectin

7 increases from the transition area between the apex and axial region in A. thaliana

8 (Chebli et al. 2012). De-esterified pectin is produced by pectin methyl esterase from

9 methyl esterified pectin, and the degree and pattern of methyl-esterification of pectin

10 influence the elasticity of the gel (Willats et al. 2001). In the transition area, remodeling

11 of the cell wall by accumulation of callose and cellulose with de-esterification of pectin

12 occurs, and this affects the aperture of the pollen tube and promotes tip-growth in $A$.

13 thaliana (Chebli et al. 2012).

14 It was expected that elongation of the rhizoid cell wall would be caused by

15 supplying the new cell wall material and remodeling of existing components to allow

16 elongation in the zygotes of S. babingtonii. We focused on the spatial distribution of

17 alginate because it is the main polysaccharide of the brown algal cell wall and relates to

18 the property of the cell wall. Therefore, immunoelectron microscopy using antibodies

19 against the different epitopes, BAM6 and BAM7, was conducted against the TCW and

20 the RTCW. There was no difference in the distribution of gold particles between the

21 thallus and rhizoid regions. A peak in the gold particle density of BAM6 was observed

22 close to the plasma membrane in the RTCW, which differs from the situation in the

23 TCW (Fig. S1). Alginate synthesis pathways in brown algae are not fully understood.

24 However, it is considered that alginate is initially synthesized as a polymer of 
1 mannuronic acid (mannuronan) by alginate synthase, and a part of the mannuronic acid

2 (M) is converted into guluronate acid (G) reside by mannuronan C5-epimerases

3 (MC5Es) (Michel et al. 2010). In other words, the M residue-rich area would be

$4 \quad$ considered to be the relatively newly synthesized alginate. Quantifying the gold

5 particles using BAM6 showed that the peaks were detected in the inner layer of TCW

6 and RTCW, and this suggests that alginate synthesis takes place at an adjacent site or on

7 the plasma membrane. In this study, the outer layer was labeled as either BAM6 or

8 BAM7. In Ectocarpus siliculosus, the alginate lyase conjugated with gold particles

9 binds to the entire cell wall but labeling with an anti-alginate antibody is limited to the

10 inner two layers of the three (Terauchi et al. 2016). Therefore, it was considered that the

11 outer layer of S. babingtonii zygotes contained alginate with different types of MG

12 blocks, which are recognized by BAM6 and BAM7. We also performed

13 immunoelectron microscopy using the anti-alginates BAM8 to BAM11 antibodies

14 (Torode et al. 2016), however they were unable to label the outer layer of the cell wall

15 in S. babingtonii zygotes.

16 Transcriptomic analysis was performed in 3-, 10-, and 24-hour-old zygotes of

17 S. babingtonii and focused on the gene expression related to alginate modification. The

18 enrichment of term "sulfotransferase activity" (GO:0008146) and "extracellular region"

19 (GO:0005576) indicate some cell wall components including sulfated fucan might be

20 actively modified during rhizoidal growth. By constructing de novo transcriptome

21 assembly, we found homologous genes required for alginate synthesis and modification

22 (Michel et al. 2010). Previous genomic or transcriptomic studies revealed that there

23 were 31 MC5E genes in Ectocarpus (Michel et al. 2010), 105 genes in Saccharina

24 japonica (Ye et al. 2015), and 38 genes in Sargassum thunbergii (Liu et al. 2014). In 
1 this study, 19 MC5E genes were identified by BLAST for the UniProt database (Table

2 S3), and the number was smaller than that of other brown algae. Because of our RNA-

3 seq data obtained from only the early developmental stage (3-24 h AF), a part of MC5E

4 genes in S. babingtonii might not be expressed. Seven S. babingtonii's MC5Es included

5 a common MC5E domain, but each MC5E included a variety of domain structures

6 similar to Ectocarpus's genes (Fischl et al. 2016). This protein domain diversity in the

7 MC5Es family contributes to the regulation of alginate composition and remodeling in

8 the cell wall. Within the data, two MC5E homologs (comp32408_c2_seq24.p1 and

9 comp33109_c0_seq1.p1) showed significantly different gene expression in embryo

10 development stages. It is known that MC5E genes show different transcript patterns in

11 different developmental times, regions, and life cycles (Nyvall et al. 2003, Tonon et al.

12 2008, Fischl et al. 2016, Linardić et al. 2020). There have been reports showing that the

13 transcripts required for rhizoid germination were synthesized up to $5 \mathrm{~h} \mathrm{AF}$ (Quatrano

14 1968, Kropf et al. 1989). From these findings, comp33109_c0_seq1.p1 may work for

15 rhizoid germination, while it is also possible that the gene may be related to the

16 expansion of the cell wall and the formation of the multilayer before rhizoid formation.

17 The expression level of comp32408_c2_seq24.p1 increased in $24 \mathrm{~h} \mathrm{AF}$, suggesting that

18 the gene would involve cell wall remodeling for rhizoid elongation.

ACKNOWLEDGEMENTS

This work was financially supported by a grant from the Sasakawa Scientific

22 Research Grant. 


\section{REFERENCE}

2 Akkerman, M., Franssen-Verheijen, M., Immerzeel, P., Hollander, L., Schel, J. \&

3

4

5

6

7

8

9

10

11

12 Emons, A. 2012. Texture of cellulose microfibrils of root hair cell walls of Arabidopsis thaliana, Medicago truncatula, and Vicia sativa. J. Microscop. 247:60-7.

Alexa, A., Rahnenführer, J. \& Lengauer, T. 2006. Improved scoring of functional groups from gene expression data by decorrelating GO graph structure. Bioinformatics. 22:1600-7.

Bisgrove, S. R. \& Kropf, D. L. 2001. Cell wall deposition during morphogenesis in fucoid algae. Planta. 212:648-58.

Brawley, S. H. \& Quatrano, R. S. 1979. Sulfation of fucoidin in Fucus embryos: IV. Autoradiographic investigations of fucoidin sulfation and secretion during differentiation and the effect of cytochalasin treatment. Dev. Biol. 73(2):193205.

Burns, A. R., Oliveira, L. \& Bisalputra, T. 1982a. A histochemical study of bud initiation in the brown alga Sphacelaria furcigera. New Phytol. 92(2):297-307.

Burns, A. R., Oliveira, L. \& Bisalputra, T. 1982b. A morphological study of bud initiation in the brown alga Sphacelaria furcigera. New Phytol. 92(2):309-25.

Callow, M. E., Coughlan, S. J. \& Evans, L. V. 1978. The role of Golgi bodies in polysaccharide sulphation in Fucus zygotes. J. Cell Sci. 32:337-56.

Chebli, Y., Kaneda, M., Zerzour, R. \& Geitmann, A. 2012. The cell wall of the Arabidopsis pollen tube - spatial distribution, recycling, and network formation of polysaccharides. Plant Physiol. 160:1940-55. 
1 Cho, H. T. \& Cosgrove, D. J. 2002. Regulation of root hair initiation and expansin gene

2

3

4

5

6 7

8 Cribari-Neto, F., Zeileis, A. 2009. Beta regression in R. J. Stat. Softw. 34:1-24.

9 Criscuolo, A. \& Gribaldo, S. 2010. BMGE (Block Mapping and Gathering with 10 expression in Arabidopsis. Plant cell. 14(12):3237-53.

Chi, E. S., Henry, E. C., Kawai, H. \& Okuda, K. 1999. Immunogold-labeling analysis of alginate distributions in the cell walls of chromophyte algae. Phycol. Res. 47:53-60.

Cosgrove, D. J. 2015. Plant expansins: diversity and interactions with plant cell walls. Curr. Opin. Plant Biol. 25:162-72. Entropy): A new software for selection of phylogenetic informative regions from multiple sequence alignments. BMC Evol. Biol. 10.

Dardelle, F., Lehner, A., Ramdani, Y., Bardor, M., Lerouge, P., Driouich, A. \& Mollet, J. C. 2010. Biochemical and immunocytological characterizations of arabidopsis pollen tube cell wall. Plant Physiol. 153:1563-76.

Delignette-Muller, M. L. \& Dutang, C. 2015. fitdistrplus: An R package for fitting distributions. J. Stat. Softw. 64:1-34.

Emons, A. M. C. \& Wolters-Arts, A. M. C. 1983. Cortical microtubules and microfibril deposition in the cell wall of root hairs of Equisetum hyemale. Protoplasma. $117: 68-81$

Evans, L. V. \& Holligan, M. S. 1972. Correlated light and electron microscope studies on brown algae I. Localization of alginic acid and sulphated polysaccharides in Dictyota. New Phytol. 71:1161-72.

Felsenstein, J. 1985. Confidence limits on phylogenies: an approach using the bootstrap. Evolution. 39(4):783-91. 
1 Ferguson, C., Teeri, T. T., Siika-aho, M., Read, S. M. \& Bacic, A. 1998. Location of

2

3

4 cellulose and callose in pollen tubes and grains of Nicotiana tabacum. Planta. 206:452-60.

Fischl, R., Bertelsen, K., Gaillard, F., Coelho, S., Michel, G., Klinger, M., Boyen, C., Czjzek, M. \& Hervé, C. 2016. The cell-wall active mannuronan C5-epimerases in the model brown alga Ectocarpus: from gene context to recombinant protein. Glycobiology. 26(9):973-83.

Geitmann, A., Li, Y. Q. \& Cresti, M. 1995. Ultrastructural immunolocalization of periodic pectin depositions in the cell wall of Nicotiana tabacum pollen tubes. Protoplasma. 187:168-71.

Guindon, S., Dufayard, J. F., Lefort, V., Anisimova, M., Hordijk, W. \& Gascuel, O. 2010. New algorithms and methods to estimate maximum-likelihood phylogenies: Assessing the performance of PhyML 3.0. Syst. Biol. 59:307-21.

Haas, B. J., Papanicolaou, A., Yassour, M., Grabherr, M., Blood, P. D., Bowden, J., Couger, M. B., Eccles, D., Li, B., Lieber, M., MacManes, M. D., Ott, M., Orvis, J., Pochet, N., Strozzi, F. Weeks, N., Westerman, R., William, T., Dewey, C. N., Henschel, R., LeDuc, R. D., Friedman N. \& Regev, A. 2013. De novo transcript sequence reconstruction from RNA-seq using the Trinity platform for reference generation and analysis. Nat. Protoc. 8:1494-512.

Huang, Y., Niu, B., Gao, Y., Fu, L. \& Li, W. 2010. CD-HIT Suite: a web server for clustering and comparing biological sequences. Bioinformatics 26:680-82. Inoue, A., Satoh, A., Morishita, M., Tokunaga, Y., Miyakawa, T., Tanokura, M. \& Ojima, T. 2016. Functional heterologous expression and characterization of 
mannuronan C5-epimerase from the brown alga Saccharina japonica. Algal Res. 16:282-91.

Karyophyllis, D., Katsaros, C. \& Galatis, B. 2000. F-actin involvement in apical cell morphogenesis of Sphacelaria rigidula (Phaeophyceae): mutual alignment between cortical actin filaments and cellulose microfibrils. Eur. J. Phycol. 35:195-203.

Katoh, K., Misawa, K., Kuma, K. I., \& Miyata, T. 2002. MAFFT: a novel method for rapid multiple sequence alignment based on fast Fourier transform. Nucleic Acids Res. 30(14):3059-66.

Kinjo, S., Monma, N., Misu, S., Kitamura, N., Imoto, J., Yoshitake, K., Gojobori, T. \& Ikeo, K. 2018. Maser: One-stop platform for NGS big data from analysis to visualization. Database. 2018:1-12.

Kloareg, B. \& Quatrano, R. S. 1988. Structure of cell walls of marine algae and ecophysiological functions of the matrix polysaccharides. Oceanogr. Mar. Bio. Annu. Rev. 26:259-315.

Kropf, D. L., Hopkins, R. \& Quatrano, R. S. 1989. Protein synthesis and morphogenesis are not tightly linked during embryogenesis in Fucus. Dev. Biol. 134:452-61.

Lefort, V., Longueville, J.E. \& Gascuel, O. 2017. SMS: Smart Model Selection in PhyML. Mol. Biol. Evol. 34:2422-4.

Lemoine, F., Entfellner, J. B. D., Wilkinson, E., Correia, D., Felipe, M. D., De Oliveira, T., \& Gascuel, O. 2018. Renewing Felsenstein's phylogenetic bootstrap in the era of big data. Nature. 556(7702):452-6. 
1 Lemoine, F., Correia, D., Lefort, V., Doppelt-Azeroual, O., Mareuil, F., Cohen-

2

3

4 Boulakia, S. \& Gascuel, O. 2019. NGPhylogeny.fr: new generation phylogenetic services for non-specialists. Nucleic Acids Res. 47(W1):W260-5.

Linardić, M. \& Braybrook, S. A. 2017. Towards an understanding of spiral patterning in the Sargassum muticum shoot apex. Sci. Rep. 7:13887.

Linardić, M., Cokus, S. J., Pellegrini, M., Braybrook, S. A. 2020. Growth of the Fucus embryo: insights into wall-mediated cell expansion through mechanics and transcriptomics. bioRxiv. https://doi.org/10.1101/2020.01.29.925107

Liu, F., Sun, X., Wang, W., Liang, Z. \& Wang, F. 2014. De novo transcriptome analysis-gained insights into physiological and metabolic characteristics of Sargassum thunbergii (Fucales, Phaeophyceae). J. Appl. Phycol. 26:1519-26.

Mabeau, S. \& Kloareg, B. 1987. Isolation and analysis of the cell walls of brown algae: Fucus spiralis, F. ceranoides, F. vesiculosus, F. serratus, Bifurcaria bifurcata and Laminaria digitata. Jour. Exp. Bot. 38:1573-80.

Michel, G., Tonon, T., Scornet, D., Cock, J. M. \& Kloareg, B. 2010. The cell wall polysaccharide metabolism of the brown alga Ectocarpus siliculosus. Insights into the evolution of extracellular matrix polysaccharides in Eukaryotes. New Phytol. 188:82-97.

Nagasato, C., Inoue, A., Mizuno, M., Kanazawa, K., Ojima, T., Okuda, K. \& Motomura, T. 2010. Membrane fusion process and assembly of cell wall during cytokinesis in the brown alga, Silvetia babingtonii (Fucales, Phaeophyceae). Planta. 232:287-98. 
1 Nagasato, C. \& Motomura, T. 2002. Ultrastructural study on mitosis and cytokinesis in

2

3

4 Scytosiphon lomentaria zygotes (Scytosiphonales, Phaeophyceae) by freezesubstitution. Protoplasma. 219:140-9.

Novotny, A. M. \& Forman, M. 1975. The composition and development of cell walls of Fucus embryos. Planta. 122:67-78.

Nyvall, P., Corre, E., Boisset, C., Barbeyron, T., Rousvoal, S., Scornet, D., Kloareg, B. \& Boyen, C. 2003. Characterization of mannuronan C-5-epimerase genes from the brown alga Laminaria digitata. Plant Physiol. 133:726-35.

Patro, R., Duggal, G., Love, M. I., Irizarry, R. A. \& Kingsford, C. 2017. Salmon provides fast and bias-aware quantification of transcript expression. Nat. Methods. 14:417-9.

Pearson, G., Lago-Leston, A., Valente, M. \& Serrã o, E. 2006. Simple and rapid RNA extraction from freeze-dried tissue of brown algae and seagrasses. Eur. J. Phycol. 41:97-104.

Popper, Z. A., Michel, G., Hervé, C., Domozych, D. S., Willats, W. G. T., Tuohy, M. G. Kloareg, B. \& Stengel, D. B. 2011. Evolution and diversity of plant cell walls: from algae to flowering plants. Annu. Rev. Plant Biol. 62:567-90.

Provasoli, L. 1968. Media and prospects for the cultivation of marine algae, In: Watanabe A, Hattori A (eds) Cultures and collections of algae. Proc US Japan Conf Hakone, Jap. Soc. Plant Physiol. 63-75.

Quatrano, R. S. 1968. Rhizoid formation in Fucus zygotes: dependence on protein and ribonucleic acid syntheses. Science. 162:468-70.

Quatrano, R. S. 1973. Separation of processes associated with differentiation of twocelled Fucus embryos. Dev. Biol. 30(1):209-13. 
1 Quatrano, R. S. \& Crayton, M. A. 1973. Sulfation of fucoidan in Fucus embryos: I.

2

3

4

5

6

7

8

9

10 Possible role in localization. Dev. Biol. 30:29-41.

Quatrano, R. S. \& Stevens, P. T. 1976. Cell wall assembly in Fucus zygotes: I. Characterization of the polysaccharide components. Plant Physiol. 58:224-31.

Rabillé, H., Torode, T. A., Tesson, B., Bail, A. L., Billoud, B., Rolland, E., Panse, S. L., Jam, M. \& Charrier, B. 2019. Alginates along the filament of the brown alga Ectocarpus help cells cope with stress. Sci. Rep. 9:12956.

Skriptsova, A. V., Shevchenko, N. M., Tarbeeva, D. V., \& Zvyagintseva, T. N. 2012. Comparative study of polysaccharides from reproductive and sterile tissues of five brown seaweeds. Mar. biotechnol. 14(3):304-11.

Sun, J., Nishiyama, T., Shimizu, K. \& Kadota, K. 2013. TCC: An R package for comparing tag count data with robust normalization strategies. $B M C$ Bioinformatics. 14(1):219.

Terauchi, M., Nagasato, C., Kajimura, N., Mineyuki, Y., Okuda, K., Katsaros, C., \& Motomura, T. 2012. Ultrastructural study of plasmodesmata in the brown alga Dictyota dichotoma (Dictyotales, Phaeophyceae). Planta. 236(4):1013-26.

Terauchi, M., Nagasato, C., Inoue, A., Ito, T. \& Motomura, T. 2016. Distribution of alginate and cellulose and regulatory role of calcium in the cell wall of the brown alga Ectocarpus siliculosus. Planta. 244:361-77.

Team, R. C. 2020. R: A language and environment for statistical computing. R Foundation for Statistical Computing, Vienna, Austria

Tonon, T., Rousvoal, S., Roeder, V. \& Boyen, C. 2008. Expression Profiling of the Mannuronan C5-Epimerase multigenic family in the brown alga Laminaria Digitata (phaeophyceae) under biotic stress conditions. J. Phycol. 44:1250-6. 
1 Torode, T. A., Marcus, S. E., Jam, M., Tonon, T., Blackburn, R. S., Hervé, C., \& Knox,

2

3

4 5

6 J. P. 2015. Monoclonal antibodies directed to fucoidan preparations from brown algae. PLoS One. 10(2):e0118366.

Torode, T. A., Siméon, A., Marcus, S. E., Jam, M., Le Moigne, M. A., Duffieux, D., Knox, J. P. \& Hervé, C. 2016. Dynamics of cell wall assembly during early embryogenesis in the brown alga Fucus. J. Exp. Bot. 67:6089-100.

Vreugdenhil, D., Dijkstra, M. L., \& Libbenga, K. R. 1976. The ultrastructure of the cell wall of normal and apolar embryos of Fucus vesiculosus. Protoplasma. 88(24):305-13.

Willats, W. G. T., Orfila, C., Limberg, G., Buchholt, H. C., van Alebeek, G. J., Voragen, A. G. J., Marcus, S. E., Christensen, T. M., Mikkelsen, J. D., Murray, B. S. \& Knox, J. P. 2001. Modulation of the degree and pattern of methylesterification of pectic homogalacturonan in plant cell walls: implications for pectin methyl esterase action, matrix properties, and cell adhesion. J. Biol. Chem. 276:19404-13.

Wu, X., Wang, G. \& Fu, X. 2014. Variations in the chemical composition of Costaria costata during harvest. J. Appl. Phycol. 26:2389-96.

Xu, P., Donaldson, L. A., Gergely, Z. R. \& Staehelin, L. A. 2007. Dual-axis electron tomography: a new approach for investigating the spatial organization of wood cellulose microfibrils. Wood Sci. Tech. 41:101-16. 
$1 \quad$ Figure Legends

2 Fig. 1. Silvetia zygote development. (a-d) 30 min AF, 12 h AF, 20 h AF, 24 h AF,

3 respectively. Arrows and arrowheads indicate the first and second cytokinetic planes,

4 respectively. (e) Illustration indicating three cell wall regions observed by TEM; the

5 thallus cell wall (diagonal dot line area), the rhizoid-flank cell wall (striped area), and

6 the rhizoid-tip cell wall (plane area). Scale bars $=50 \mu \mathrm{m}(\mathrm{a}-\mathrm{d})$

7

8 Fig. 2. Ultrastructure of (a) TCW, (b) RFCW, and (c) RTCW in zygotes at $12 \mathrm{~h} \mathrm{AF}$.

9 Arrows show the outer edge of cell wall. Arrowheads show plasma membrane. IL; the

10 inner layer, ML; the middle layer, OL; the outer layer. Scale bars=500 nm.

12 Fig. 3. Zygotes at $24 \mathrm{~h} \mathrm{AF}$. (a) Fraction of the Silvetia rhizoid. A double arrowhead 13 indicates the point from which the two outer layers start to be reduced. (b) Oblique 14 section of TCW. The cell wall consists of three layers. (c) Perpendicular section of 15 TCW. (d) RFCW. The outer layer is disappearing. (e) RFCW. The middle layer fades 16 away. (f) RTCW has only one layer, which is made of rough fibrils. Thick mucilage

17 covers the rhizoid. Arrows indicate the outer edge of cell wall. Arrowheads show

18 plasma membrane. IL; the inner layer, ML; the middle layer, OL; the outer layer. Scale 19 bars $=10 \mu \mathrm{m}(\mathrm{a}), 500 \mathrm{~nm}(\mathrm{~b}-\mathrm{f})$

20

21 Fig. 4. Immunogold localization of alginate within cell wall in the zygotes at $24 \mathrm{~h} \mathrm{AF}$.

22 (a), (b), (c) shows BAM6 localization. (d), (e), (f) indicates BAM7 localization. (a) (d)

$23 \mathrm{TCW}$, (b) (e) RFCW, (c) (f) RTCW. Arrows show the outer edge of cell wall.

24 Arrowheads show plasma membrane. Scale bars=500 nm (a-f) 
2 Fig. 5. Quantitative analysis of putative Mannuronan C5-epimerase genes transcript

3 level in 3, 12, and 24 hour-old zygotes. (a) comp32408_c2_seq24.p1, (b)

4 comp33109_c0_seq1.p1. The relative gene expression was set one at $3 \mathrm{~h}$ AF. The error

5 bars indicate SDs of three separate experiments. Tukey's multiple comparison tests were

6 conducted to investigate significant differences between the treatment hours. Asterisks

$7 \quad(*)$ indicate significant differences at $\mathrm{P}<0.01$.

8

9 Fig. S1. The distribution of the relative density of relative distance of gold particles

10 binding to BAM6 and BAM7 in TCW and TRCW at $24 \mathrm{~h}$-old zygotes. The relative

11 distance between plasma membrane and the cell-wall edge ranges from 0 to 1 . The sum

12 of density is adjusted to 10 . Red lines show the function obtained by kernel function and

13 bandwidth.

14

15 Fig. S2. Three different embryo developmental stages for transcriptomic analysis. (a) 3

$16 \mathrm{~h} \mathrm{AF}$, (b) $10 \mathrm{~h} \mathrm{AF,} \mathrm{(c)} 24 \mathrm{~h} \mathrm{AF.}$

17

18 Fig. S3. MA plots (log expression ratio vs. mean average expression) comparing gene

19 expression during zygote germination. Differential expression genes were shown as magenta points (TCC, FDR < 0.05). (a) $3 \mathrm{~h}$ AF vs. $10 \mathrm{~h} \mathrm{AF,} \mathrm{(b)} 3 \mathrm{~h}$ AF vs. $24 \mathrm{~h} \mathrm{AF,} \mathrm{(c)}$

$21 \quad 10 \mathrm{~h} \mathrm{AF}$ vs. $24 \mathrm{~h} \mathrm{AF}$.

22

23 Fig. S4. Schematic representation of the alginic acid biosynthetic pathways with

24 expression levels of putative enzymatic genes during embryo development. The gene 
1 expression level was shown as TPM and Z-score. MPI: mannose-6-phosphate

2 isomerase, PMM: phosphomannomutase, GMD: GDP-mannose 6-dehydrogenase,

3 MC5E: mannuronan C5-epimerase. Asterisks indicate differential expression genes.

4

$5 \quad$ Fig. S5. Phylogenetic and putative protein structural analysis of mannuronan C5-

6 epimerases in S. babingtonii. Numbers indicate the bootstrap values in the maximum

7 likelihood analysis. Asterisks indicate differential expression genes. Each shape on the

8 schematic protein sequences indicates the catalytic MC5E domain (purple box), a

9 transmembrane domain (cyan oval), a signal peptide region (orange box), and the WSC

10 domains (green box).

11

12 

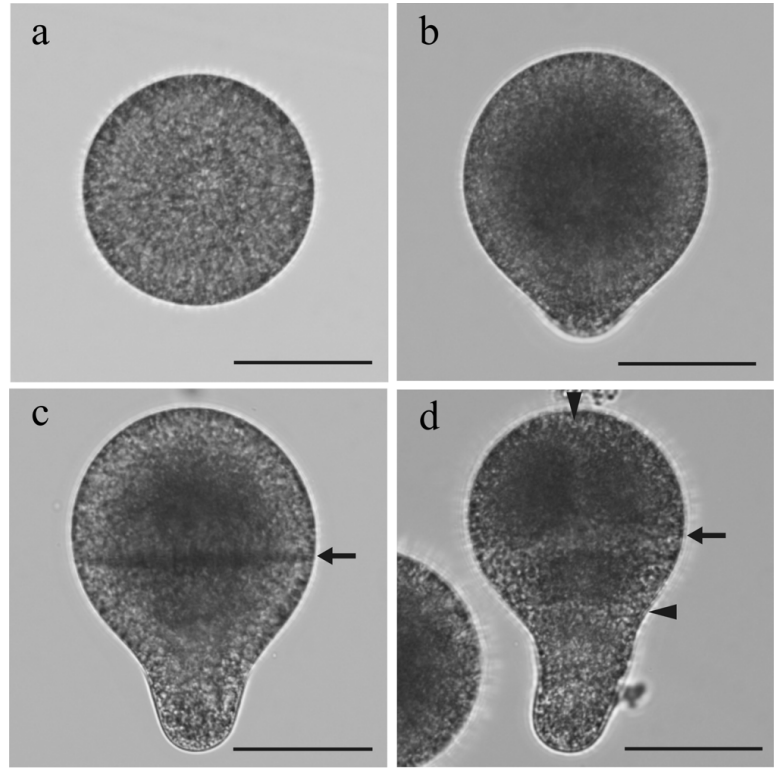

e

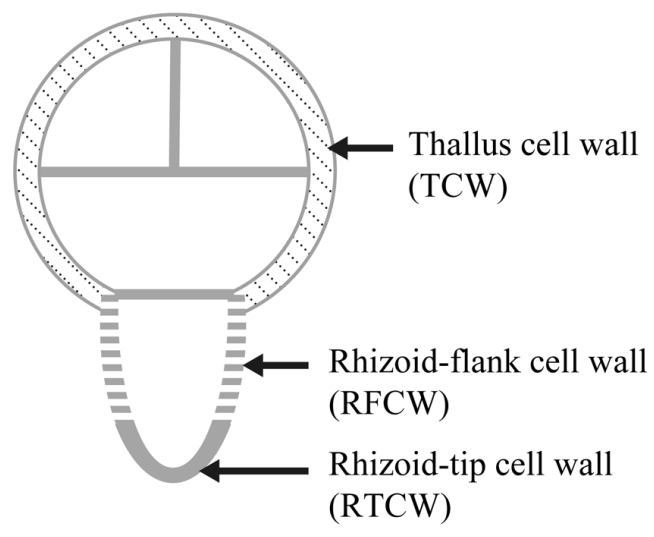

Fig. 1 


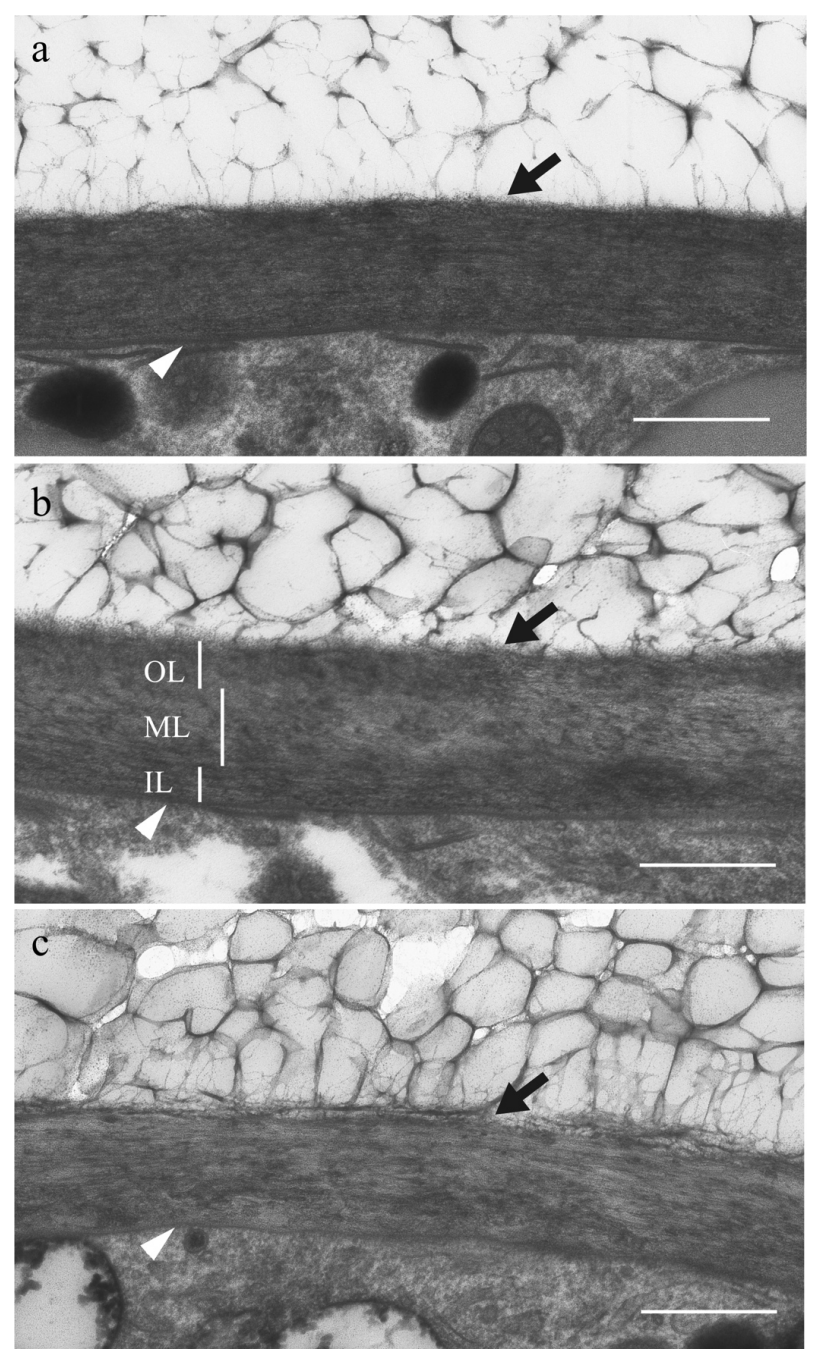

Fig. 2 


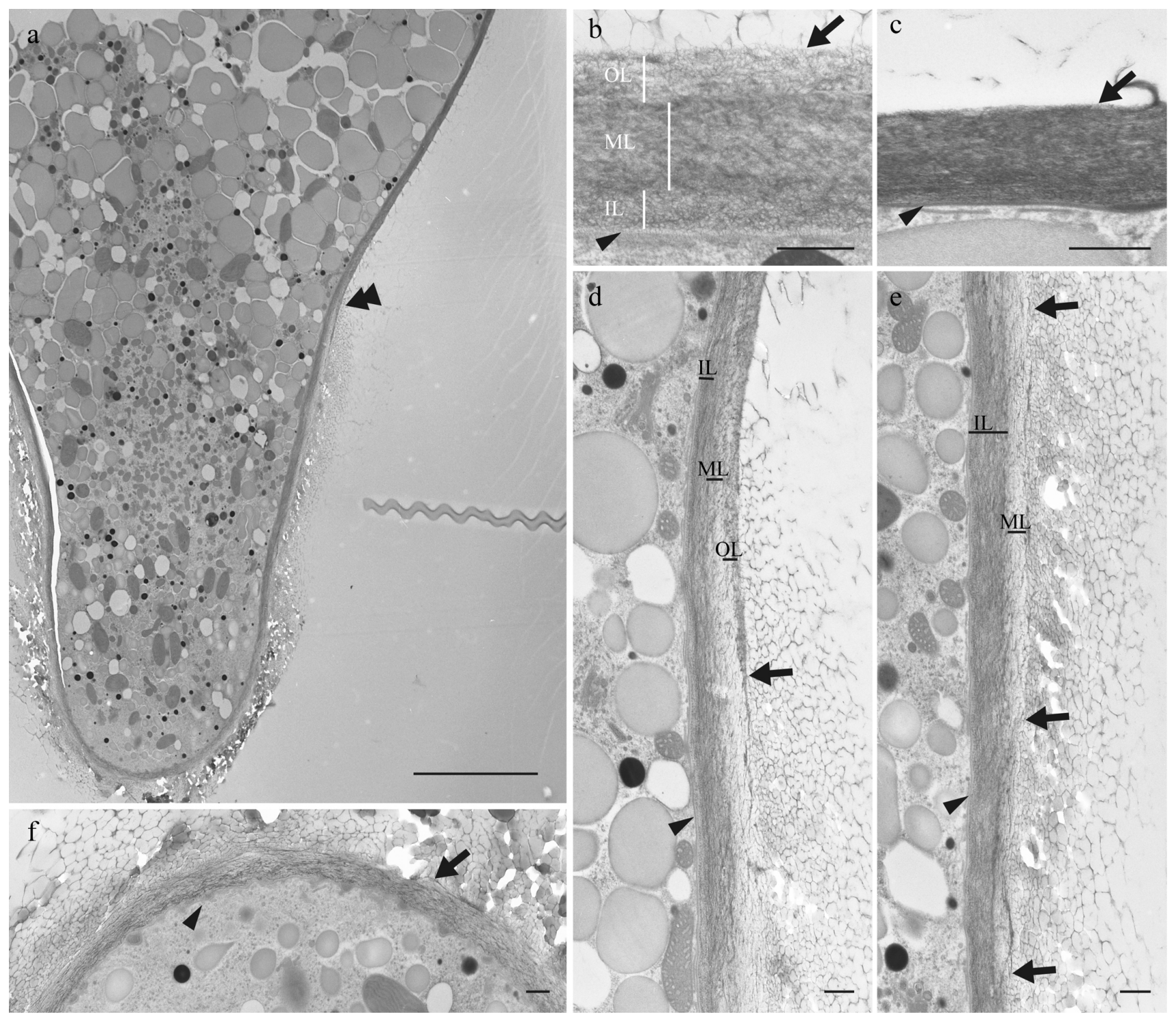

Fig. 3 


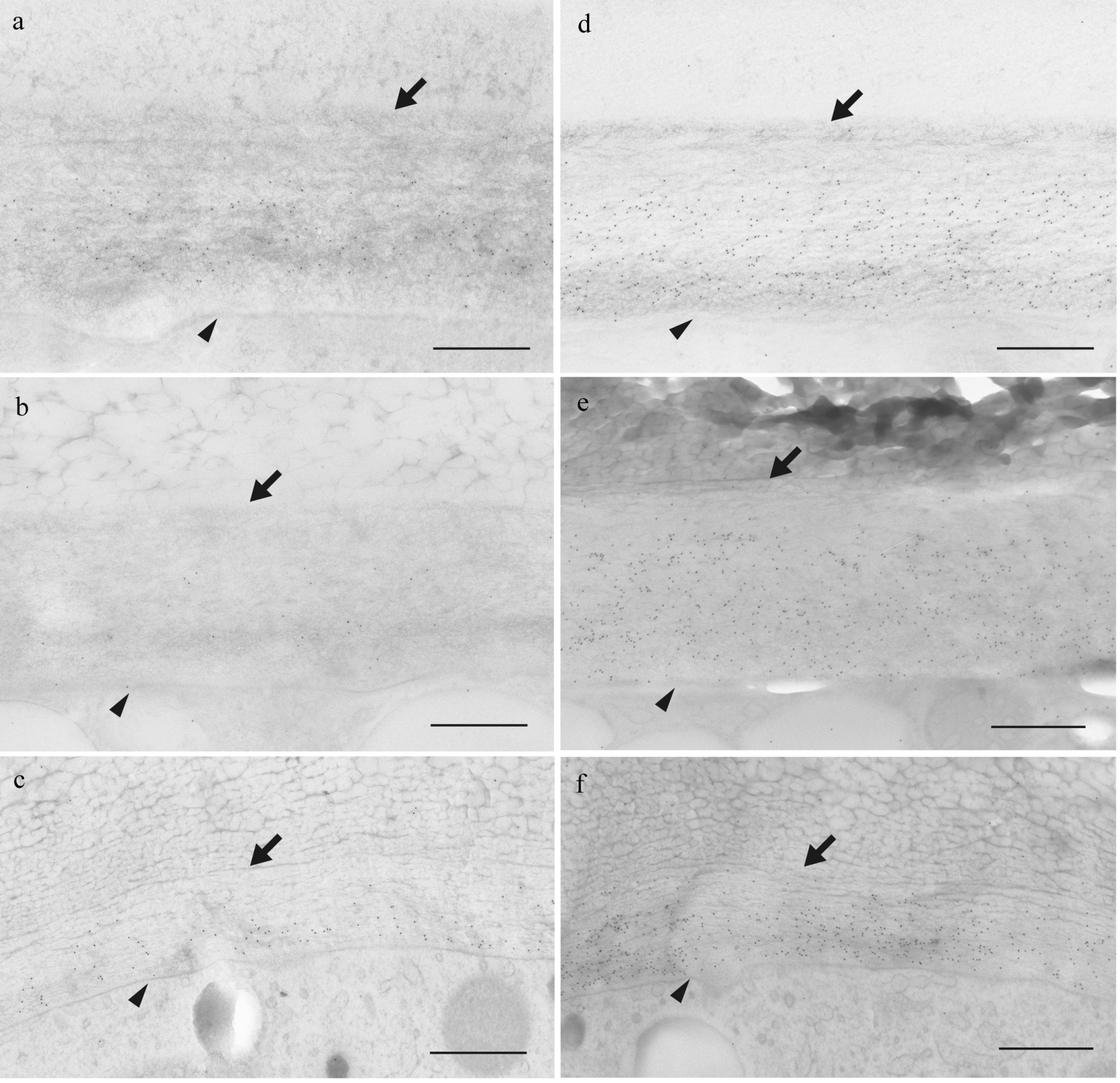

Fig. 4 
a

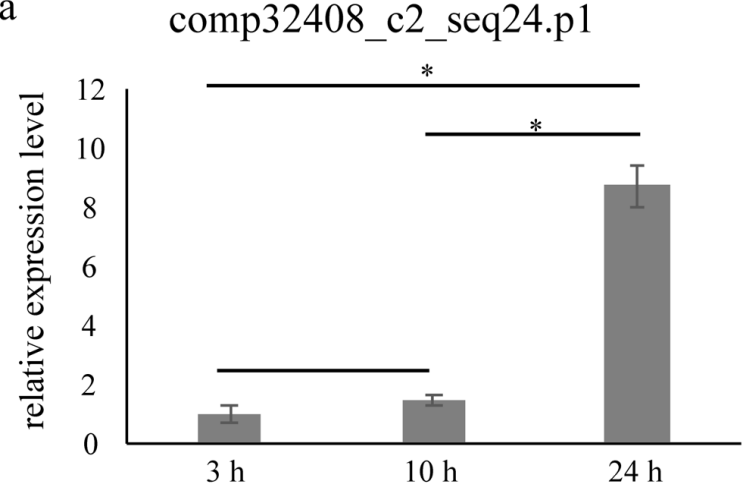

Fig. 5

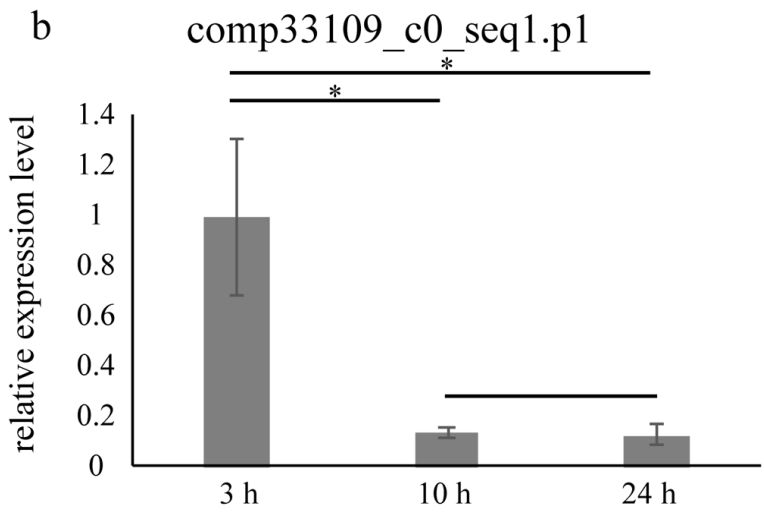



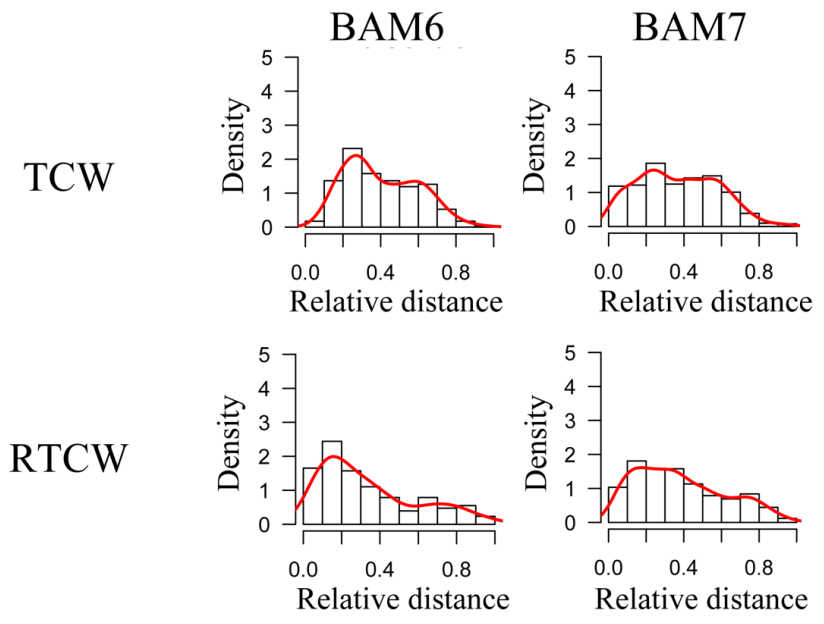

Fig. S1 

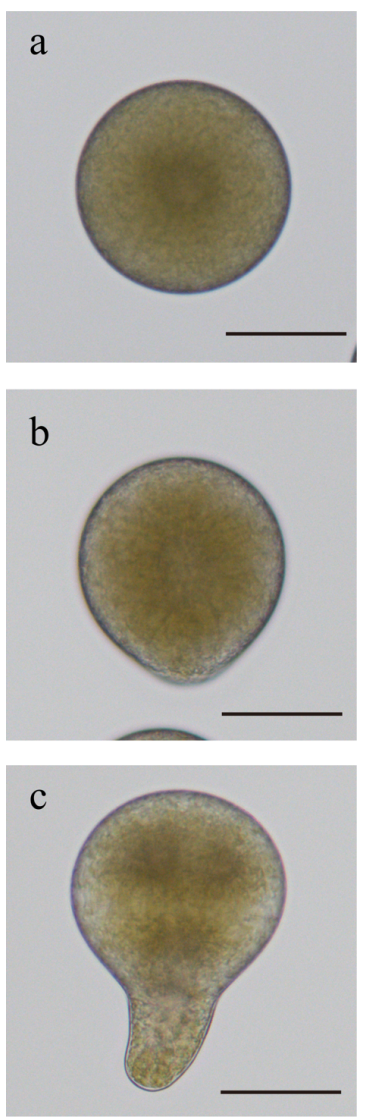

Fig. S2 

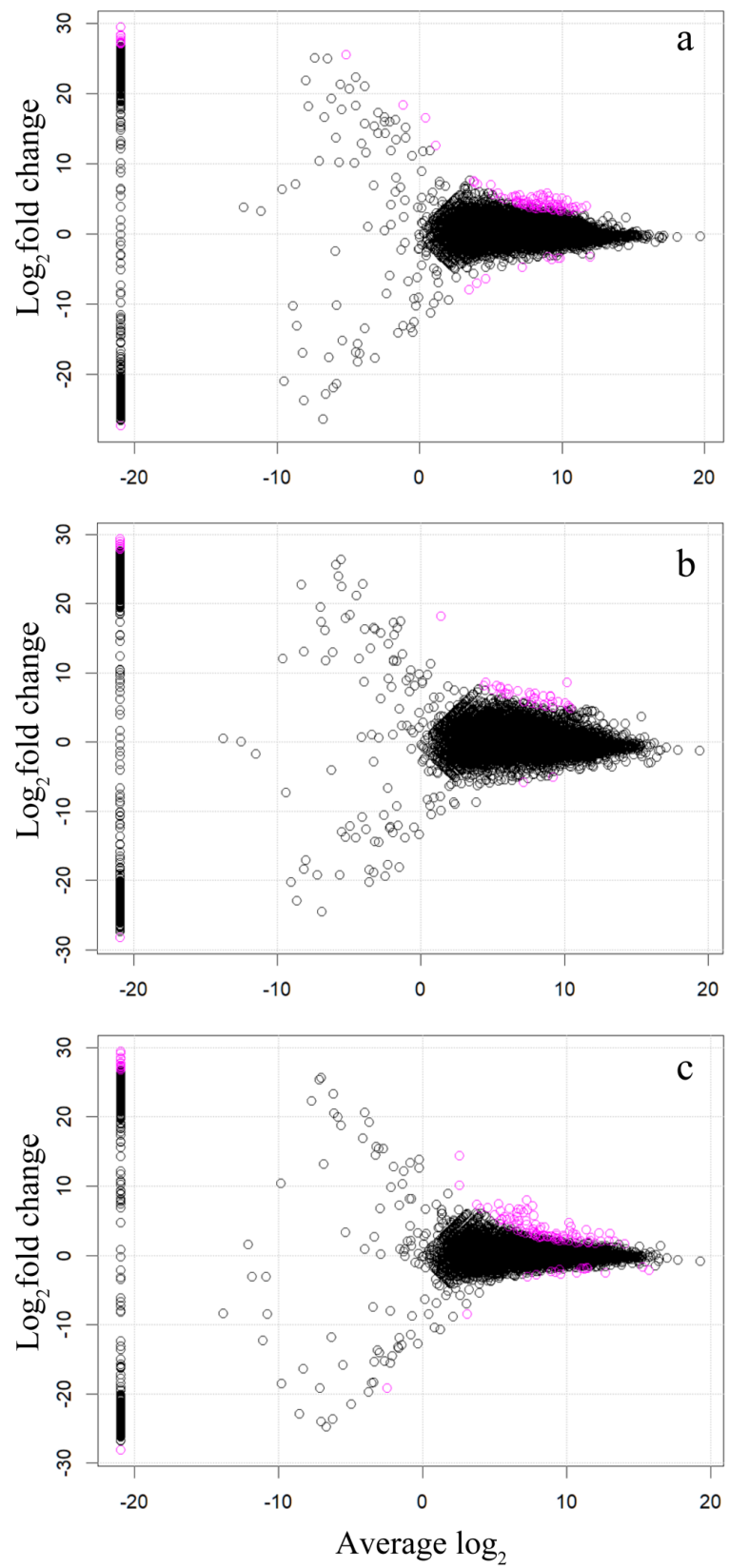

Fig. S3 


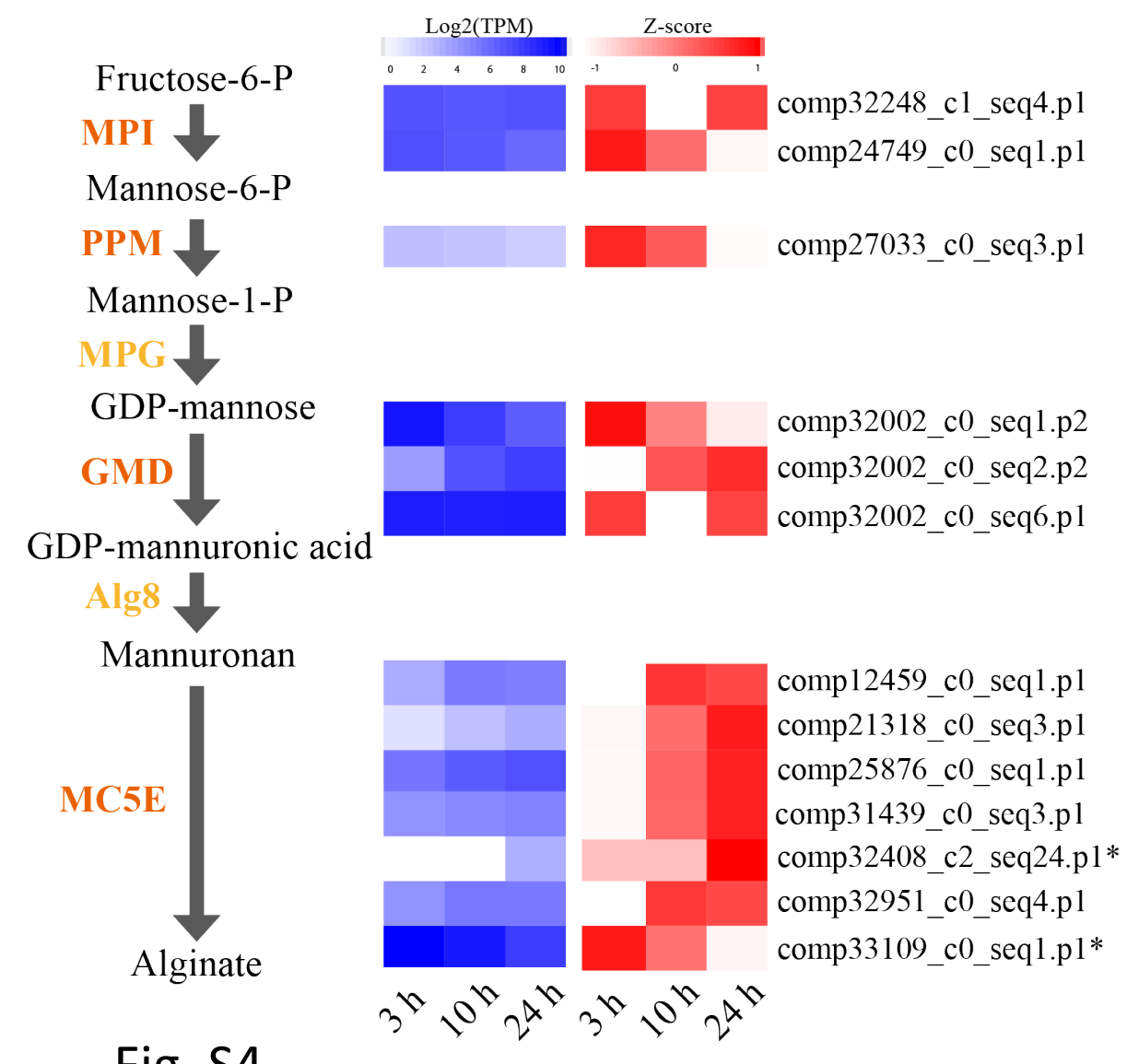

Fig. S4 


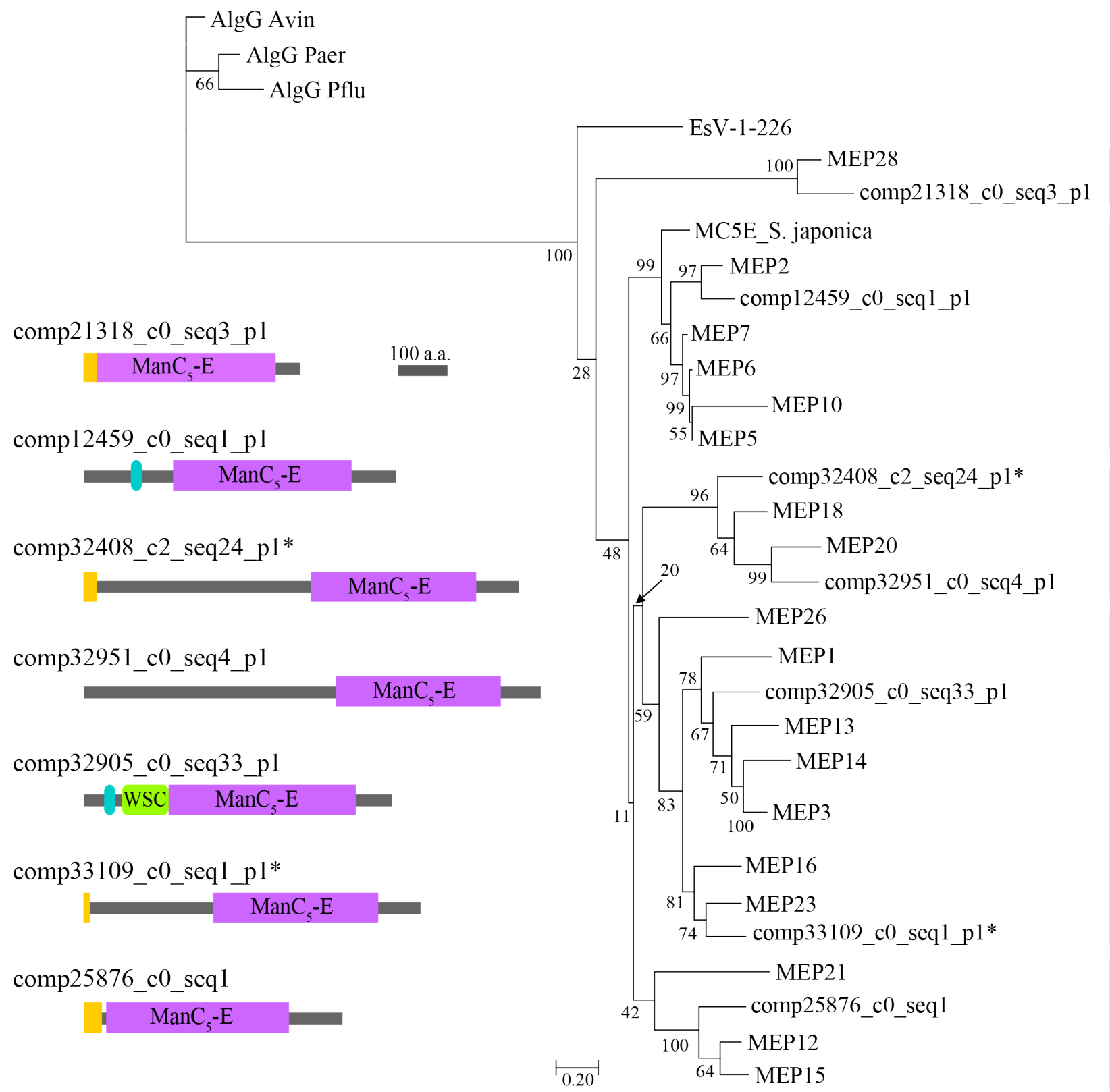

Fig. S5 